\title{
PDK1 wt Allele
}

National Cancer Institute

\section{Source}

National Cancer Institute. PDK1 wt Allele. NCI Thesaurus. Code C104759.

Human PDK1 wild-type allele is located in the vicinity of 2 q31.1 and is approximately $70 \mathrm{~kb}$ in length. This allele, which encodes [pyruvate dehydrogenase [lipoamide]] kinase isozyme 1, mitochondrial protein, plays a role in carbohydrate metabolism. 